\title{
IKIMOKYKLINIO AMŽIAUS VAIKŲ BENDROSIOS MOTORIKOS POVEIKIS KALBINEI MOTORIKAI (ARTIKULIACIJAI)
}

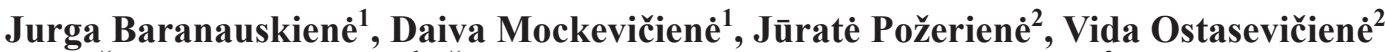 \\ Šiauliu universitetas ${ }^{1}$, Šiauliai, Lietuvos kūno kultūros akademija ${ }^{2}$, Kaunas, Lietuva
}

\begin{abstract}
Jurga Baranauskienè. Edukologijos magistrè. Šiaulių universiteto Medicinos pagrindų katedros asistentè. Mokslinių tyrimų kryptis — ikimokyklinio amžiaus vaikų judesio korekcija.
\end{abstract}

\section{SANTRAUKA}

Tyrimo metu analizuota, kaip bendrosios motorikos atskiri komponentai (kūno laikysena, koordinacinès funkcijos, kūno judesiai) veikia ikimokyklinio amžiaus vaiku kalbos neišlavèjima (artikuliacinio aparato būklę, artikuliacinio aparato judesiu koordinacija, garsu ir žodžiu artikuliacija) dèl dizartrijos ir alalijos.

Testavimo metodu atlikto tyrimo tikslas — nustatyti ikimokyklinio amžiaus vaiku bendrosios ir kalbinès motorikos (artikuliacijos) neišlavejima dèl dizartrijos ir alalijos, o atlikus koreliacinę analizę- bendrosios motorikos poveiki kalbinès motorikos (artikuliacijos) atskiriems komponentams.

Buvo tiriama 100 ikimokyklinio amžiaus 4-7 metu vaiku, kuriu kalba neišlavèjusi dèl dizartrijos ir alalijos. Empirinèje dalyje nagrinejjami kūno laikysenos, koordinaciniu, kūno judesiu funkciju ir artikuliacinio aparato būklès, judesiu koordinacijos, artikuliacijos koreliaciniai ryšiai. Ivertinus ikimokyklinio amžiaus vaiku, kuriu kalba neišlavejjusi, laikysena nustatyta: apie 20\% vaiku turi ̨̇vairiu laikysenos nukrypimu, geriausiai išlavinę tirtas kūno judesiu funkcijas, silpniausiai - judesiu koordinacija. Ivertinus ikimokyklinio amžiaus vaiku, kuriu kalba neišlavejjusi, artikuliacinio aparato būklę nustatyta: geriausiai išsivystęs artikuliacinis aparatas, o judesiu koordinacija, garsu ir žodžiu artikuliacija — vidutiniškai (surinko atitinkamai $60 \mathrm{ir}$ 65\% balu).

Išvados: 1) ikimokyklinio amžiaus tarpsniu artikuliacinius judesius, kalbos garsu ir žodžiu artikuliacija iš bendrosios motorikos komponentu labiausiai veikia pusiausvyra, šiek tiek mažiau judesiu koordinuotumas (tiek ranku, tiek koju), silpniausiai jie veikia artikuliacinio aparato būklę; 2) šio amžiaus vaiku kūno laikysena visai neveikia artikuliacijos.

Raktažodžiai: ikimokyklinis amžius, bendroji motorika, kalbinè motorika.

\section{IVADAS}

$\mathbf{J}$ udesių raida sutampa su smegenu brendimu. Smegenų kamienas subręsta greičiau nei žievẻ ar nugaros smegenys. Pirmiausia subręsta smegenų zonos, valdančios galvos, kaklo ir liemens raumenis, todèl vaikas iš pradžiu pakelia, pasuka galvą, vartosi, vèliau sẻdasi, vaikšto. Vèliausiai subręsta zonos, kurios valdo kojų ir rankų raumenis (Mockevičienè ir kt., 2005). Tad motorinès raidos kryptis - nuo galvos link kojų, nuo visumos prie dalies, o smulkiosios motorikos nuo proksimalinès link distalinès, t. y. nuo centro iki periferijos. Kiekvieną naują motorini igūdi vaikas išmoksta ankstesniujų pagrindu. Išmokęs išlaikyti svorị, vaikas pradeda stovèti, vaikščioti (Ališauskienè, 1998; Mikulènaitė, 2003). Oralinio aparato raida priklauso nuo viso kūno judesiu raidos, raumenų tonuso, kuri valdo centrinè nervu sistema (Gružaite ir kt., 2004). Mokslininkai tei- 
gia, kad kuo ankstesniu amžiaus tarpsniu koreguojama bendroji motorika, tuo galimi mažesni kalbos vystymosi pakenkimai (Журба, Мастюкова, 1981; Ivoškuvienè, 1986; Gordon, 1987; Ališauskienė, 1998; Mockevičienè ir kt., 2005).

Normali kūno kontrolè reiškia atskirų kūno dalių gebėjimą disocijuotai (atskirai) funkcionuoti. Disocijuoti judesiai iki galo susiformuoja, kai kontroliuojama rotacija apie kūno ašį, ir tai leidžia disocijuotai funkcionuoti galūnèms ir oraliniam aparatui. Taigi gebejjimas kontroliuoti liemens judesius veikia smulkiają motoriką ir vaiko kalbą (Bobath, K., Bobath, B., 1984). Tuo tarpu kalbos motorika visiškai priklauso nuo judejjimo sistemos veiklos ir negali be jos normaliai funkcionuoti. Visas judejimo atramos aparatas apibūdinamas kaip būtinas kalbos raidos pagrindas. Oralinio aparato raumenu sistema tampa vaiko kalbos turinio ir formos „statybininkais“ (König, 1994). Taigi bendras motorikos vystymasis ankstyvoje vaikysteje būtinas pagrindas, padedantis formuotis kalbai (Unčiurys, 1988). Motorikos pažeidimo nebūna be kalbos sutrikimų, pavyzdžiui, mikčiojantysis mikčioja ir vaikščiodamas, ir kvėpuodamas, t. y. visa motorika dalyvauja tame mikčiojime; paralyžiuotas vaikas būtinai turès kalbos problemu (König, 1995).

Analizuojant vaikų, turinčių nedidelio laipsnio dizartrija, anamnezès duomenis galima pastebèti, kad kai kurių motorinė raida vèlavo: galvos vertikaliai nulaikyti negalèjo iki 5-7 mènesių, savarankiškai sèdèti — iki 8-9 mènesių (kai kada ir iki metų), vaikščiojimą ịvalde tik apie antruosius metus. Dalis šiu vaiku, net pradejję vaikščioti laiku, vaikščiojo šuoliais, besikaitaliojančiais su bėgimu, jau išmokę vaikščioti labiau norèdavo šliaužioti, buvo perdètai atsargūs ir vaikščiojo labai lètai arba ilgą laiką ant pirštų galų (Лопатина, 2003). Vaikų, turinčių dizartrijos požymių, motorikos sutrikimai atskirais atvejais labai įvairūs ir nevienodi: pastebimas nevikrumas, nejudrumas, susikaustymas, lètumas, kai kada apriboti vienos kūno pusès judesiai, judejimas hiperaktyvus, būdingas neramumas, greitas judesių tempas, daugelis judesių atliekant valingus ir nevalingus veiksmus bereikšmiai (Garšvienė, Ivoškuvienė, 1993; Мастюкова, 1988; Волкова, 1989; Фотекова 2003; Лопатина, 2003). Specialiojoje literatūroje, analizuojančioje kalbos sutrikimus, daugiau aprašomi ir analizuojami smulkiosios (rankų) ir kalbinès motorikos sutrikimai, o bendrosios motorikos raida ir judejimo igūdžių formavimasis apibūdinamas fragmentiškai (ypač ikimokyklinio ir mokyklinio amžiaus tarpsniu), dažniausiai konstatuojamas faktas, kad bendroji motorika išsivysčiusi nepakankamai, sutrikusi atliekamų judesių apimtis, tikslumas ir koordinacija (Лопатина, 2003).

Pastebèti vienokie ar kitokie bendrosios motorikos sutrikimai tų vaikų, kurių kalba neišlavejjusi, bet nepavyko aptikti tyrimų, atsakančių i klausima, ar lavinant tam tikrus bendrosios motorikos komponentus galima pakoreguoti kalbą (pvz., nustatytas smulkiosios motorikos poveikis kalbèjimo lavejjimui). Bendrosios motorikos pagrindu formuojasi smulkioji motorika: ranku ir kalbinè motorika (artikuliacija), nuo paprastesnių stambiu judesių einama prie smulkesnių sudètingesnių, būtent ikimokyklinio amžiaus tarpsniu smarkiai tobulejja kalba, tikslejja jos garsų artikuliacija.

Tyrimu keltas probleminis klausimas: ar yra ryšys bendrosios motorikos (laikysenos, kūno judesių funkcijų, judesių koordinacijos) ir kalbinès motorikos (artikuliacijos) ryšys ir kaip jis veikia ikimokyklinio amžiaus vaikus?

Tyrimo tikslas - nustatyti ikimokyklinio amžiaus vaikų bendrosios motorikos (laikysenos, kūno judesių funkcijos ir judesių koordinacijos) poveiki kalbinei motorikai (artikuliacijai).

Tyrimo objektas - ikimokyklinio amžiaus vaiku, kurių kalba neišlavèjusi, bendrosios ir kalbinès motorikos (artikuliacijos) ryšys.

\section{TYRIMO METODIKA IR ORGANIZAVIMAS}

Tyrimas vyko logopediniame darželyje. Buvo tiriama $1004-7$ metu amžiaus vaikų, turinčiu ivvairų kalbos neišlavejjimą (mažą, vidutini ir didelị) dèl pseudobulbarinès dizartrijos ir motorinès alalijos (daugeliu atvejų buvo nustatytos abi). Buvo tiriami 35 ikimokyklinio jaunesniojo amžiaus (4-5 m.), 33 ikimokyklinio amžiaus $(5-6 \mathrm{~m}$.) ir 32 priešmokyklinio amžiaus $(6-7 \mathrm{~m}$.) vaikai. Tiriamieji pagal lyti pasiskirstę šitaip: 76 berniukai ir 24 mergaitès (darželyje nuolat dominuoja berniukai).

Norint, kad testo rezultatams neturètu itakos vaiku nuovargis, vienas vaikas buvo testuojamas ivairiais testais keletą dienu pirmoje dienos pusèje. Testavimui pasirinkti standartizuoti testai, kurie vertinami ranginèmis skalèmis (Bitinas, 2006). Bendroji motorika buvo vertinama dviem testais. Pirmaji - kūno judesiu funkciju testa (KJF) - sudaro 88 rodikliai, sugrupuoti i penkias skirtingas kūno judesių sistemas (Gelžinytė, Šlekienè, 2005). Testo metu vertintas stovejjimas, 
èjimas, bėgimas ir šokinèjimas ( 0 balų - užduotis nepradedama, 1 - pradedama, 2 - iš dalies užbaigta, 3 - visiškai užbaigta). Antraji - koordinaciniu funkciju (Schmitz, 1988) testą - sudaro 16 mèginiu (piršto-nosies, nosies-piršo kaitaliojimo mèginys, piršto-tyrejjo piršto, piršto-piršto, taikymo - nepataikymo, pronacijossupinacijos, rato piešimo ore, galūniu padèties išlaikymo, atatrankos, piršto opozicijos, daugelio sugniaužimų, plaštakos tepingo, pédos tepingo, plaštakos tepingo, kelių keitimo, kulno-blauzdos, pakaitinis kulno-kelio-piršto). Šiuo testu vertinama judesių kokybè: 4 balai - normalus kūno padèties, pozos išlaikymas arba judesys; 3 balai - judesiai arba išlaikymas kiek sunkoki, pastebimi nedideli netikslumai; 2 balai - judesiai neritmiški, ju tikslumas smarkiai mažèja didinant atlikimo greiti; 1 balas — poza arba judesiai išlaikomi sunkiai, jie labai neritmiški, netikslūs, pastebimas drebulys, pašaliniai judesiai; 0 balu — negali atlikti tikslaus judesio, išlaikyti pozos (Adomaitiené, 2003). Laikysenai tirti buvo naudojamas Hoegerio testas (Arcinavičius ir kt., 2004) - laikysena vertinama balais, apžiūrint atskirus kūno segmentus (galvos padètị, pečius, mentis, stuburą, dubeni, kelius ir čiurną, liemeni, pilva, kojas, pedas) sagitalioje (iš šono) ir frontalioje (iš nugaros, priekio) plokštumose. Kalbinei motorikai (artikuliacijai) vertinti taikyti trys testai (Garšvienè, Jankevičienè, 2002): 1) artikuliacinio aparato būklès - vertinant, kokia artikuliacinio aparato judesiu amplitude, koks veido raumenu tonusas, veido simetrija; 2) artikuliacinio aparato judesių koordinacijos - vertinant skaičiuojamas judesiu kiekis per $5 \mathrm{~s}$ atliekant ịvairias užduotis; 3) artikuliacijos - vertinant tikrinamas gebèjimas aiškiai artikuliuoti garsus: priebalsių ir balsių junginiuose, priebalsių junginiuose, daugiaskiemeniuose žodžiuose ir frazèse.

Matematinè statistika. Tyrimo rezultatai apdoroti matematinès statistikos metodais (SPSS 11.0 for Windows). Koreliacijos koeficientas $r$ tarp dviejų kintamujų buvo skaičiuojamas naudojant Spirmeno koreliacijos koeficientą, nes testų duomenys matuoti ranginèmis skalèmis. Koreliacinių tyrimų tikslas - rasti patvarius bendrosios motorikos ir kalbinės motorikos (artikuliacijos) apibendrintus ryšius. Koreliacija laikyta statistiškai reikšminga, jei $\mathrm{p}<0,05$.

\section{REZULTATAI}

Pirmiausia apžvelgsime testų rezultatus, kurie pateikti procentais nuo galimos maksimalios testo balų sumos (žr. pav.).

Iš bendrosios motorikos testu geriausiai vaikai atliko kūno judesiu funkcijų užduotis (toliau KJF). Šio amžiaus vaikai daugumą šio testo užduočiu atlieka gerai. Ne visi atliko gerai tik 18 užduočiú. Sunkiausiai sekèsi atlikti tokias užduotis, kaip eiti tiesia linija koja už kojos $(71,5 \%$ balų nuo maksimumo), šokinèti (80\%) ir stovèti (88\%) ant vienos kojos. Daugiausia taisyklingos laikysenos nukrypimų nustatyta apžiūrint šiuos kūno segmentus: mentis (63\%), pilvą (66\%), kojas $(68 \%)$, stuburo linkiu padidejjimą ar sumažejimą $(80 \%)$, pečiu asimetriją $(83 \%)$, pilnapadiškumą $(87 \%)$. Sutrikimu beveik nepasitaikè vertinant galvos, stuburo ir dubens nukrypimą $\mathfrak{i}$ šonus. Iš koordinacinių funkcijų testo užduočiu geriausiai atliko galūnių padèties išlaikymo mėgini (94\%), sunkiausiai sekèsi gerai atlikti piršto opozicijos, pronacijos-supinacijos, daugelio sugniaužimu ir plaštakos tepingo (52-60\%) užduotis. Jas atlie-

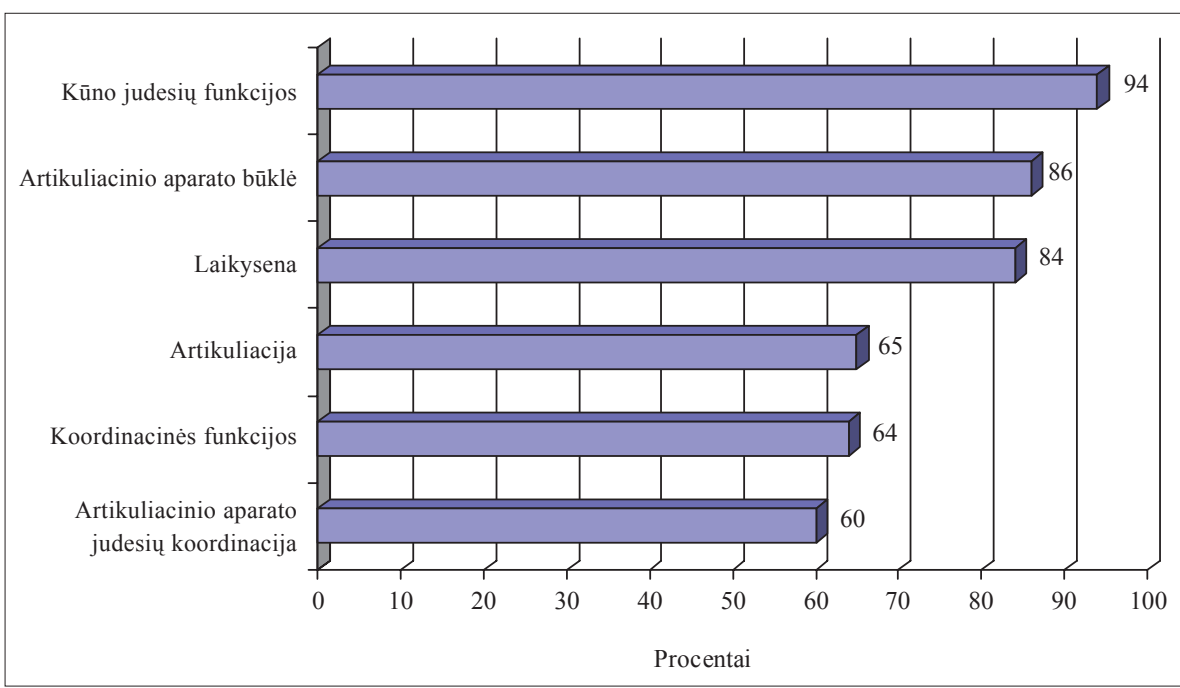

Pav. Testų rezultatų ivertinimas ( $\%$ nuo maksimumo) 
kant buvo pastebimas drebulys, o atliekant kelis kartus - neritmiškumas ir netikslumas.

Geriausi vertinimai nustatyti atliekant artikuliacinio aparato būklès testus. Sunkiausiai sekèsi atlikti tokias užduotis: išlaikyti lūpas kuo arčiau viena kitos, liežuvi judinti i šonus, nosi siekti liežuviu ( 70\%). Geriausiai įvertintos šios užduotys: veido mimikos ir šypsenos simetriškumo, išsižioti-susičiaupti ( 97\%). Atliekant artikuliacijos užduotis, sunkiausiai tiriamiesiems sekèsi gerai ištarti daugiaskiemenius žodžius (46\%), geriausiai - atvirus skiemenis (93\%). Sunkiausiai sekèsi gerai atlikti artikuliacinio aparato judesių koordinacijos užduotis. Geriausiai - per 5 s kuo daugiau kartų atlikti tokias užduotis kaip: prasižioti-užsičiaupti (86\%), skiemenų PA, TA, KA tarimo $(\sim 80 \%)$, sunkiausiai - liežuvio galiuko pakèlimo ir nuleidimo (dažnai kelti liežuvi i viršu padėdavo apatinè lūpa); liežuvio judinimo i kairę ir i dešinę (daugelis kartu judindavo ir apatini žandikauli) ( 40\%), P, T, K tarimo (46\%). Taigi blogiausiai šio amžiaus tarpsniu įvertintos tiek bendrosios, tiek kalbinès motorikos testais tos užduotys, kurios reikalauja tam tikros judesiu koordinacijos.

Bendrosios motorikos ir artikuliaciniu testu užduočių koreliaciniai ryšiai silpni ir statistiškai reikšmingi (žr. lent.).

Laikysenos ir visi artikuliaciniai testai sudare tik 3\% visų galimų silpnų statistiškai reikšmingu ryšių. Tad laikysena šio amžiaus tarpsniu artikuliacijos neveikia. Iš koordinaciniu funkcijų testo nustatyta daugiausia statistiškai reikšmingų koreliacinių ryšių su artikuliacinių testų užduotimis (piršto opozicijos, atatrankos, piršto-piršto, pèdos tepingo, kulno-blauzdos mèginiai). Atkreiptinas dèmesys i tai, kad ne tik rankos smulkiosios motorikos lavinimu galima koreguoti kalbą, bet ir kojos, ypač pėdos.

Kūno judesių funkcijų testo užduotis eiti linija koja už kojos su visomis artikuliacijos testo užduotimis sudaro esmini koreliacini ryši, su artikuliacinio aparato judesių koordinacijos testo užduotimis - 9 iš 11 , su artikuliacinio aparato būklès testo užduotimis -7 iš 21 . Tarp kūno judesių funkcijų testo 6 užduočiu (èjimo koja už kojos tiesia linija, šokinejjimo ir stovèjimo ant dešinès ir kairès kojos, pašokimo i viršu abiem kojom kartu ir artikuliacinių testų) galima pastebèti tokias tendencijas: kuo sudetingesni artikuliaciniai veiksmai, tuo stipriau (visais atŽvilgiais - ir ryšiu stiprumu, ir koreliacinių ryšiu kiekiu) jie koreliuoja su kūno judesių funkciju testo užduotimis, kurios rodo tam tikrą pusiausvyros išlavejjimą.

\section{REZULTATU APTARIMAS}

Aktyviausiai judesiai vystosi pirmaisiais gyvenimo metais. Išmokęs aktyviai judèti, vaikas pradeda gerinti judesiu kokybę. Manoma, kad trejų metų vaiko eisena labai panaši i suaugusiojo. Motorinè sistema visiškai subręsta iki septynerių-aštuonerių metų (Gelžinytė, Šlekienè, 2005). Judesių koordinacija išsivysto tik po pirmų trejų gyvenimo metų. Žmogui būdingas gebėjimas tam tikrais gyvenimo laikotarpiais geriau išmokti specialiuosius judesius, bet ju geriausiai išmokstama vaikysteje (Zaveckas, 2008). Mūsų tyrimo metu gauti duomenys parodé, kad kūno judesių funkcijas dauguma ikimokyklinio amžiaus vaikų jau yra îvaldę arba linkę gerai įvaldyti tas, kurias atliekant reikalingas tam tikras pusiausvyros ir judesių koordinacijos išlavèjimas. $32 \%$ vaikų visas kūno judesių funkcijų testo užduotis atliko puikiai ir surinko didžiausią balų skaičių (iš jų tik trys iš mažiausiuju grupès). Koordinaciniu funkciju testo didžiausios balų sumos nesurinko nè vienas vaikas: $50-75 \%$ maksimalios balų sumos surinko $69 \%$ vaiku, $11 \%$ vaiku surinko mažiau nei pusę balų ir 20\% - daugiau nei $75 \%$. Šie rodikliai nuo amžiaus nepriklauso. Panašių šios amžiaus grupès tyrimų nepavyko rasti.

Lietuvoje dažniausiai atliekami atskirų vaikų grupių (mokyklos, darželio) laikysenos tyrimai. Skirtingu autorių duomenimis, netaisyklinga

Lentelè. Artikuliacinių ir bendrosios motorikos testų užduočių koreliaciniai statistiškai reikšmingi ryšiai (\% nuo maksimumo)

Pastaba. ${ }^{*}$ - pateiktos 6 kūno judesių funkcijų testo užduotys (èjimo koja už kojos tiesia linija, stovèjimo ir šokinèjimo ant dešinès ir ant kairès kojos, pašokimo ị viršu abiem kojom kartu), koreliavusios su artikuliacinių testų užduotimis.

\begin{tabular}{|l|c|c|c|}
\hline \multicolumn{1}{|c|}{$\begin{array}{r}\text { Bendrosios motorikos } \\
\text { testai }\end{array}$} & Laikysenos & $\begin{array}{c}\text { Koordinacinių } \\
\text { funkcijų }\end{array}$ & $\begin{array}{c}\text { Kūno judesių } \\
\text { funkcijų* }\end{array}$ \\
\hline Artikuliaciniai testai & & $21 \%$ silpnų ryšių & $26 \%$ silpnų ryšių \\
\cline { 3 - 4 } $\begin{array}{l}\text { Artikuliacinio aparato būklès } \\
\text { koordinacijos }\end{array}$ & \multirow{2}{*}{$3 \%$ silpnų ryšių } & $37 \%$ silpnų ryšių & $\begin{array}{c}52 \% \text { silpnų ryšių, } \\
12 \% \text { esminių ryšių }\end{array}$ \\
\cline { 3 - 4 } Artikuliacijos & & $55 \%$ silpnų ryšių & $\begin{array}{c}54 \% \text { silpnų ryšių, } \\
46 \% \text { esminių ryšių }\end{array}$ \\
\hline
\end{tabular}


laikysena būdinga nuo 26,5 iki 60,9\% ikimokyklinukų (Jasiūnas ir kt., 2002). Profilaktinių patikrinimu duomenys rodo laikysenos sutrikimu didejimo tendenciją ne tik mokyklinio, bet ir ikimokyklinio amžiaus vaikų grupèse: $1991 \mathrm{~m}$. laikysenos sutrikimai buvo nustatyti 1,0\% ikimokyklinio amžiaus vaikų, $2001 \mathrm{~m}$. — 2,7\% (Juškelienè, 2003). V. Juškelienè (1998), tyrinèjusi pečiu, menčių, klubų ir talijos trikampių asimetrijos paplitimą tarp 6-7 metų Vilniaus ikimokykliniu istaigu vaikų, nurodo, kad laikysena sutrikusi $46,9 \%$ vaikų. Klaipėdos lopšelyje-darželyje „Želmenèlis" asimetrinè laikysena diagnozuota 23,5\% 3-6 metų amžiaus vaikų (Žmuidienè, 1998). 2000 m. Vilniaus lopšelị-darželị „Pušaite““ pradejjo lankyti $43 \%$ lopšelinio amžiaus vaiku, kuriu kūno laikysena jau buvo netaisyklinga (Zimbienė, 2000). Šiauliu krašte priešmokyklinuku laikysena ir jos paplitimą tyrę D. Mockevičiené ir J. V. Vaitkevičius (2002) nustate $60,9 \%$ vaiku kūno laikysenos asimetriją. Mūsų eksperimento metu tiriant laikyseną Hoegerio testu, didžiausios balų sumos nesurinko nè vienas vaikas, bet pagal ši testą $11 \%$ vaiku laikysena yra puiki, $56 \%$ gera ir $33 \%$ - patenkinama. Šios proporcijos panašios visose amžiaus grupèse, kinta tik tai, kad su amžiumi didejja pečių ir menčių asimetrija, mažèja pilnapadžių vaikų. Mūsų tyrimo duomenų lyginti su anksčiau minètais nelabai i̇manoma, nes skiriasi vertinimo metodika ir šiuo testu tiriant ikimokyklinukus nėra atskleidžiami fiziologiniai laikysenos ypatumai, būdingi šio amžiaus tarpsnio vaikams. Be to, stuburo intensyvaus vystymosi laikotarpiu ypač auga 4-6 metų mergaičiu ir 6-8 metu berniuku slanksteliai, o raumenu, raiščiu augimas atsilieka $1-2$ metais. Todèl šiuo amžiaus tarpsniu pastebimi laikysenos pakitimai, menčiu ar pečiu juostos asimetrija - normalus reiškinys (Saniukas, 2008). Priešmokykliniu laikotarpiu stambieji raumenys išsivysto gerai, o pilvo, liemens ir smulkieji nugaros raumenys dar silpni. Lenkiamujų raumenų tonusas yra kur kas didesnis negu tiesiamuju (Adaškevičienè, 2004). Todèl paprastai ikimokyklinukai laikysenos sutrikimu neturi ir iš šalies žiūrint dažniausiai sunku pasakyti, ar tokio mažylio laikysena taisyklinga, ar ne, nes jie retai kada nustygsta vietoje (Saniukas, 2008).

Logopedas kiekvienais metais prieš pradèdamas dirbti su vaiku tiria artikuliaciją, bet nepavyko rasti medžiagos, kur šie duomenys būtu surinkti ir apibendrinti. Galima palyginti A. Garšvienès ir V. Jankevičienès (2002) tyrimo, nagrinėjusio Robertson metodikos tinkamumą ikimokyklinio amžiaus vaikų nedidelio laipsnio dizartrijai atskleisti, duomenis. Jos ištyrè 19 priešmokyklinès grupès vaikų, kuriems nustatyta dizartrija, ir kontrolinę normalios kalbos raidos vaiku grupę. Aptiktas akivaizdus skirtumas tarp normalios kalbos raidos ir nedidelio kalbos sutrikimo ikimokyklinuku artikuliacinio aparato judesių koordinacijos ir artikuliacijos testų rezultatų. Atlikdami artikuliacinio aparato judesių koordinacijos ir artikuliacijos testų užduotis, normalios kalbos raidos vaikai atitinkamai surinko 77 ir $90 \%$ baluc, o tie, kuriems nustatyta dizartrija, atitinkamai 55 ir 63\% balų (Garšvienè, Jankevičienè, 2002). Mūsų tyrimo metu gauti rezultatai yra panašūs (atitinkamai 60 ir $65 \%$ ). Vaikai, neturintys kalbos sutrikimu, ne visas užduotis atliko gerai, nes ne visu artikuliacinè motorika tobula, tačiau yra prisitaikę ir kalba visiškai aiškiai, taisyklingai taria garsus, be to, juk testų užduotys nėra ịprastos (Garšvienè, Jankevičienè, 2002).

Kalbos trūkumus gali lemti motorikos sutrikimas (Garšvienė, Ivoškuvienè, 1993; Мастюкова, 1988). Vienu gali būti sutrikusi tik kalbinè motorika, kitu smulkiosios artikuliacinio aparato motorikos sutrikimas yra bendrosios motorikos sutrikimo dalis (Garšvienè, Ivoškuvienè, 1993). Dèl įvairiu dizartriju pakitęs raumenų tonusas (padidejęs arba sumažejęs) lemia kalbos padargų raumenų tonusą ir padèti (Мастюкова, 1988). Atlikto tyrimo duomenimis, laikysena šiuo amžiaus tarpsniu artikuliacijos neveikia, bet ji gali lemti tokius kalbos komponentus kaip fonacija (Drąsutienè, 2006) ir pan. Koreguojant artikuliacijos sutrikimus, daugiausia iš bendrosios motorikos tirtu komponentu gali padeti pusiausvyros ir judesių koordinacijos lavinimas. Juk kuo sudètingesnès artikuliacinès užduotys, tuo stipresniais koreliaciniais ryšiais jos susijusios su pusiausvyros ir tikslesnès judesių koordinacijos reikalaujančiomis užduotimis. Kaip teigia A. Garšvienė ir R. Ivoškuvienė (1993), bendrosios motorikos tyrimas svarbus logopedui nustatant kalbos sutrikimo priežastis ir organizuojant visapusišką kalbos korekciją. Taigi mes, remdamiesi savo tyrimo rezultatais, galime pasiūlyti tokias motorikos tyrimo užduotis: stovejjimą ant vienos kojos, fiksuojant laiką, šokinejjimą ant vienos kojos (10 kartu $61 \mathrm{~cm}$ skersmens rate), ejimą koja už kojos 10 žingsniu i prieki tiesia linija ( $2 \mathrm{~cm}$ pločio), piršto opozicijos, atatrankos, piršto-piršto, pedos tepingo ir kulno-blauzdos mèginius. 


\section{IŠVADOS}

Išanalizavus bendrosios (judesio, padèties) ir kalbinès (artikuliacijos) motorikos koreliacinius ryšius nustatyta: hipotezè pasitvirtino tik iš dalies, t. y. ikimokyklinio amžiaus tarpsniu vaiku artikuliacinius judesius ir kalbos garsų, žodžiu artikuliaciją stipriausiai iš bendrosios motorikos komponentu veikia pusiausvyros išlavejjimas ir šiek tiek mažiau judesių koordinuotumas (tiek rankų, tiek kojų), silpniausiai jie veikia artikuliacinio aparato būklę. Kūno laikysena ikimokyklinio amžiaus tarpsniu artikuliacijos raidos neveikia.

\section{LITERATŪRA}

Adaškevičienè, E. (2004). Vaiku fizinès sveikatos ir kūno kultūros ugdymas: monografija. Klaipeda: Klaipèdos universitetas.

Adomaitienè, R. (Sud.). (2003). Taikomoji neigaliuju fiziné veikla. Kaunas: Lietuvos kūno kultūros akademija.

Ališauskienė, S. (1998). Ankstyvojo amžiaus vaiku korekcinis ugdymas. Šiauliai: Šiaulių universiteto leidykla.

Arcinavičius, S. A., Kesminas, R., Milčarek, E. (2004). Laikysena ir jos vertinimo aspektai. Kineziterapija,1 (5), $28-35$.

Bitinas, B. (2006). Edukologinis tyrimas: sistema ir procesas. Vilnius: KRONTA.

Bobath, K., Bobath, B. (1984). The neurodevelopmental tetrament. In D. Scrutton (Ed.), Management of the Motor Disorders of Children with Cerebral Palsy. London: Spastics International Medical Publications.

Drąsutienè, G. (2006). Tausokime kalbos balsq. Kaunas.

Garšviene, A., Ivoškuvienè, R. (1993). Logopedija. Kaunas: Šviesa.

Garšvienè, A., Jankevičienė, V. (2002). Dizartrijos simptomatikos ivertinimas. Specialusis ugdymas, 2 (7), 93 103.

Gelžinytė, K., Šlekienė, I. (2005). Kūdikiu psichomotorinès sistemos raida ir jos diagnostika. Panevėžys: Panevėžio kolegija.

Gordon, J. (1987). Assumptions Underlying Physical Therapy Intervention: Theoretical and Historical Perspectives. Foundations for Physical Therapy in Rehabilitation. Rockville, MD: Aspen Publishers.

Gružaite, V., Ivoškuvienė, R., Martusevičienė, V., Pečiulienè, O. (2004). Rijimo sutrikimu šalinimas. Šiauliai: VšI Šiaulių universiteto leidykla.

Ivoškuvienè, R. (1986). Ankstyvoji kalbejimo korekcija. Vilnius.

Jasiūnas, V., Mauricienè, V., Kilkienè, I., Sinickienė, V. (2002). Moksleiviu netaisyklingos laikysenos paplitimas ir jos nustatymo svarba. Reabilitacijos metodu ir priemoniu efektyvumas: Lietuvos reabilitologu asociacijos konferencijos medžiaga (pp. 188-189), Birštonas.

Juškelienè, V. (1998). Asimetrinès laikysenos rizikos veiksniai ir pokyčiai tarp 6-8 metu vaiku: daktaro disertacija. Vilnius.

Juškelienè, V. (2003). Sveikata ir fizinis aktyvumas. Vilnius: Vilniaus pedagoginis universitetas.

König, K. (1994). Die ersten drei Jahre des Kindes. Stuttgart: Verlag Freies Geistesleben.
König, K. (1995). Sinnesentwicklung und Leiberfahrung. Stuttgart: Verlag Freies Geistesleben.

Mikulènaite, L. (2003). Bendrosios ir smulkiosios motorikos raida. Kn. S. Ališauskienè, V. Gudonis, L. Mikulènaitè, J. Petrulytè, L. Radzevičienè (Aut.), Ankstyvasis ugdymas: dabartis ir perspektyvos. Šiauliai: V̌̌ı Š Siauliu universiteto leidykla.

Mockevičienė, D., Mikelkevičiūtè, J., Adomaitienė, R. (2005). Vaiku motorikos raida. Šiauliai: Všı Šiaulių universiteto leidykla.

Mockevičienė, D., Vaitkevičius, J. V. (2002). Priešmokyklinukų asimetrinė laikysena ir jos paplitimas Šiaulių krašte. Specialusis ugdymas, 1 (6), 60-64.

Saniukas, K. (2008). Netaisyklinga laikysena [žiūrèta 200801 15]. Prieiga internetu: http://www.lsveikata.lt/ index.php?page_id $=48 \&$ s $=877$

Unčiurys, J. (1988). Vaiku kalbos trūkumai ir ju šalinimas. Kaunas: Šviesa.

Zaveckas, V. (2008). Su centrine nervu sistema labiausiai susijusios fizinès ypatybès: pusiausvyra, koordinacija, judesiu valdymas ir mokymasis, vikrumas [žiūrèta 200801 15]. Prieiga internetu: http://www.vsv.lt/mokymas

Zimbienè, O. (2000). Kaip ugdome taisyklingą laikyseną. Vaiku sveikatos stiprinimas: dabartis ir perspektyvos: konferencijos medžiaga (pp. 101-102), Vilnius.

Žmuidiené, G. (1998). Ikimokyklinio amžiaus vaikų taisyklingos laikysenos ugdymas. Sveikata ir kūno kultūra: praeitis, dabartis ir ateitis: respublikinès mokslinès konferencijos medžiaga (p. 64), Kaunas.

Волкова, Л. С. (Ред.). (1989). Логопедия. Москва: Просвещение.

Журба, Л. Т., Мастюкова, Е. М. (1981). Общие подходы к коррекции задержки психомоторного развития. Л. Т. Журба, Е. М. Мастюкова (Авт.), Нарушение психомоторного развития детей первого года жизни. Москва: Медицина.

Лопатина, Л. В. (2003). Изучение и коррекция нарушений психомоторики у детей с минимальными дизартрическими расстройствами. Дефектология, 5, 45-51.

Мастюкова, Е. М. (1988). Речевые нарушения. Л. О. Бадалян, Л. Т. Журба, О. В. Тимонина (Авт.), Детские церебральные параличи. Киев.

Фотекова, Т. А. (2003). Состояние и динамика высших психических функцый у школьников с общим недоразвитием речи и задержкой психического развития. Дефектология, 1, 23-33. 


\title{
THE INFLUENCE OF GROSS MOTOR MOVEMENTS ON LINGUISTIC MOTOR DEVELOPMENT OF PRESCHOOL CHILDREN
}

\author{
Jurga Baranauskienè ${ }^{1}$, Daiva Mockevičienè ${ }^{1}$, Jūratė Požerienė ${ }^{2}$, Vida Ostasevičienè ${ }^{2}$ \\ University of Šiauliai ${ }^{l}$, Šiauliai, Lithuanian Academy of Physical Education ${ }^{2}$, Kaunas, Lithuania
}

\begin{abstract}
The influence of separate components of gross motorics such as the body posture, coordination functions, movements of the body on such components of linguistic motor development as the state of articulator apparatus, coordination of movements of articulator apparatus and articulation of sounds and words of preschool age children with language delayed development due to disartry and alalia is analysed in this work.

Applying the methods of testing and the the correlation analysis research the goal of which was to establish the development of gross motorics and linguistic motorics (articulation) of children of preschool age with language delayed development due to disartry and alalia was carried out to ascertain the influence of separate components of general motorics on separate components of linguistic motor (articulation). 100 children of preschool age (from 4 to 7 years of age) having language delayed development due to disartry and alalia took part in the research.

In the empirical part the correlation between the body posture, coordination functions, functions of the movements of the body and the state of articulator apparatus, coordination of its movements, articulation were investigated. After the evaluation of posture, coordination functions, functions of movements of the body of preschool age children with language delayed development the following was established: the investigated functions of the movements of the body were mastered the best of all tasks, there were also about $20 \%$ of different divergences from the correct posture, and the coordination of movements was developed the least. After the evaluation of the state of articulator apparatus, coordination of movements of articulation apparatus and articulation of children of preschool age with language delayed development the following was established: the state of articulator apparatus was the most developed one and the coordination of movements of the articulation apparatus and articulation of sounds and words was developed on the average level (correspondingly 60 and $65 \%$ points out of the maximum).

Conclusions: 1) the development of balance has the strongest influence on articulational movements and articulation of sounds of the language and words from all of the components of general motorics at preschool age and the coordination of movements (both of the arms and legs) has a little bit less influence, their influence on the state of articulation apparatus is the weakest; 2) at this age the posture of the body does not influence the articulation at all.
\end{abstract}

Keywords: preschool age, gross motorics, articulation (linguistic motorics).

Gauta 2008 m. liepos 1 d.

Received on July 1, 2008

Priimta 2009 m. gegužès $6 \mathrm{~d}$.

Accepted on May 6, 2009

\author{
Jurga Baranauskienè \\ Šiauliu universitetas \\ (University of Šiauliai) \\ Višinskio g. 25, LT-76351 Šiauliai \\ Lietuva (Lithuania) \\ Tel +370 41595735 \\ E-mailmedicinosk@cr.su.lt
}

